\title{
ETHICAL ASPECTS OF PRIVATIZATION PROCESS IN THE PUBLIC AGRICULTURE SECTOR
}

\author{
Jarosław Mioduszewski \\ University of Warmia and Masuria in Olsztyn, Poland \\ miodus@uwm.edu.pl
}

\begin{abstract}
Lease of farm lands is the most important process of proprietorial changes in the state's agriculture sector. As an effect of turbulent socio-economic conditions and legal solutions resulting from country's agricultural politics, its share in land's management has significantly shrunk. Currently there is around 1.1 million ha of land in lease, which makes up for $23 \%$ of the land acquired by the Agricultural Property Agency of the State Treasury. After 23 years of 3.2 million ha of lands acquired by the Resource $(68.5 \%)$ has already been managed permanently and 2.5 million ha (53\%) have been sold. Lease allows fast temporary management of the farm lands acquired by the State's Treasury, and a buyingout, mostly by the hitherto leaseholders, afterwards. The range and the structure of area of sales agreement of farm lands indicates that it was acquired by a relatively small group of buyers. Such a structure of permanent management of the State's Treasury's farm lands might bring some hesitations and questions on rationality of the proprietorial changes from the social interest view and ethics.
\end{abstract}

Key words: management, business ethics, agricultural property of the State Treasury.

\section{Introduction}

The beginning of the process of proprietorial changes in the state's agriculture sector in Poland dates back to 1990. Farm households had to adapt quickly to new conditions due to the change of socio-economic system. As a result of the change, financial situation of most households got worse which strongly affected state households. This has led to serious losses since 1991. Reshaping and remodelling of the system was based on the Act on the Management of Agricultural Real Estate of the State Treasury (AMAREST) from October 19, 1991. The Act enabled introducing the Agricultural Property Agency of the State Treasury, which was formed to execute proprietary rights and other property rights of the State Treasury's farm properties. The Agricultural Property Agency (APA) is its legal successor (Runowski, 2013; Fedejko \& Others, 1993).

Though national agriculture sector has never been dominant, it had a significant manufacturing and political role. In the late 1990s national sector made up for $19 \%$ of farm lands and produced $18 \%$ of global agricultural production, $19 \%$ of the final production and $21 \%$ of merchandise ${ }^{1}$. National share in agriculture was varied spatially. It covered most parts in the regions of northern and western Poland. As a result of management of agricultural real estate, the scale of the problem and outcomes of proprietorial changes of the sector show significant spatial differentiation (Ziętara, 2013; Marks-Bielska, 2010; Marks-Bielska, 2013; Marks-Bielska, 2014b).

A term of privatization is closely connected with a process of proprietorial changes. It means limiting state's role in management or in property rights in favour of the private sector. Following Savas
(1992) changing proprietorial right from state to private is supposed to lead to better, fuller and more efficient fulfilment of society's needs. He stresses the connection of privatisation process with several various motives such as pragmatic, ideological, economic and populist. The pragmatic motif indicates that the privatisation should be delivered wisely which would increase its effectiveness and efficiency of the management. The ideological motif assumes limitation of the state's influence in favour of private institutions. It shows that government's decisions are based politically; therefore, they are less trustworthy that the decisions based on the rules of market economy. The economic motif is based on the assumption that state's enterprises and properties might be used better when being private and this will allow the country gaining more profit as the burden would be passed on private objects. The last mentioned motif (populist) assumes that privatization offers a bigger spectrum of social services. Moreover, it allows people to define their needs and creates feeling of companionship. It is then based on blood or neighbour bound or on a bound resulting from being a part of various voluntary associations rather than on bounds created by developed bureaucracy.

Adam Smith formulated basic rules leading to 'National treasure'. He indicates that three prerogatives play important roles in economic development and those are: endeavouring one's benefits, sharing workload and free trade which should benefit both sides of the transaction (Rourke, 2009). Bearing in mind that striving for richness is nothing bad, ethical behavior of participants of the trade are more of the value. Penc (2003) defines ethics of behaviour as "spectrum of socially accepted within a society moral

1 Statistical Agriculture Yearbook 1993, CSO, Warsaw 
norms prescribing duties and deciding on moral orientation as well as people's moral practice, on their choices made in complex and difficult situations, when equal values and moral rules seem to eliminate one another". Chosen ethic rules have significant influence on moral consciousness of people and determine their behavior. Business ethics should be also mentioned in this context as a direct outcome of idea of Corporate Social Responsibility (CSR). CSR is a concept according to which, at the level of forming as well as while running a business, enterprises should nurture social interest, environmental protection and their relationship with various groups of interest. Assessed by stakeholders, CSR plays the main role in business. Carroll (2009) suggested four dimensions that describe CSR:

- Philanthropic - associated with realisation of programmes supporting society, engaging in helping local society and volunteering,

- Ethic-expected by the society and determining its actions according to law, avoiding unwanted behaviours and providing with ethical leadership,

- Legal - required by the society and connected with protection of natural environment, consumers rights, obeying anticorruption laws and delivering contracts,

- Economical - required by the society, connected with maximisation of profits and minimisation of costs as well as choosing right strategic decisions.

Economic dimension of corporate social responsibility refers to Milton Friedman's opinion. He finds it the only right way to gain profit and obeying law. Currently most conceptions of CSR join mentioned forms of social responsibility and refer to need of obeying both ethical, moral and legal norm in business. At the same time they extend the frames of traditionally perceived ethics and law (Goodpaster \& Matthews Jr., 2007; Wieteska-Rosiak, 2012) ${ }^{2}$

Penc (2003) describes the business ethics as 'serious reaction on legal regulations, market signals and needs of society and environment, as well as foreseeing employers intentions and trends in economy in order to act beneficially for the environment'. As a base of ethical management he suggests running a business according to public interest without a necessity of using legal force of any specific moral norm. According to him, ethical actions are those which are motivated by one's own benefit only when they do not influence negatively social interest. As this follows, ethical actions not only require well written law referring to corporate social responsibility, but also rules of economy, which would make ethics beneficial and unethical actions might lead to bankruptcy. In this context, norms and values formed by companies which directly or indirectly take part in the process of management of agricultural properties and at the same time are facing problems and decisional struggles, might be a matter of research. Such approach is an excuse for looking for connections between stakeholders (institutions, contractors and other objects with legal personality) and using knowledge from the spectrum of ethics and using it in economic practice.

\section{Materials and Methods}

This paper is an attempt of describing the process of proprietorial changes in state's sector with a reference to values of business ethics. Analysis and assessment is based on statistical data referring to management of agricultural properties of the State Treasury in years 1992 - 2014 and legal-formal regulations referring to the trade of farm lands.

\section{Results and Discussion}

The change of the socio-political system which started in the middle of 1989 was the main reason of privatisation of state's agricultural sector. The introduced system was based on the rules of market economy and it resulted in unleashing prices, limiting or liquidation of material dotation, introducing strict anti-inflation policy and opening the market for foreign markets (Jaworowski, 1999; Mioduszewski, 2006; Sadowski, 2009). Transformation of proprietary relations was an indicator of upcoming proprietary changes in agriculture. It was mostly directed towards limiting the state's property and increasing and strengthening private property through privatisation of management initially (agricultural lands' administration and lease), and then through full privatisation of agricultural properties finally. In over 23 years of the formed trust institution, four characteristic periods resulting from realization given proprietary rights of the State Treasury can be listed (Nawrocki \& Podgórski, 2009; Mioduszewski \& Niedzielski, 2012; Figure 1):

- I period (1992 - 1995) - actions focused mostly on acquisition of agricultural properties to the Resource of CAP (a total of 4.4 MLN ha which constituted for $93.2 \%$ of properties under acquisition). Most of the properties came from the acquired 1666 national agricultural properties. After the acquisition properties functioned as Agricultural Properties of The State Treasury under temporary management.

2 following: A.B. Carroll: Business and Society: Ethics and Stakeholder Management, College Division South-Western Publishing Co, Cincinnati, Ohio, 1993. 
Restructuration plans were prepared and on the base of them, the final forms of management were chosen. The acquired properties were managed mainly in a form of lease (over 2.7 MLN ha $-62 \%$ ). A part of Agricultural Properties of The State Treasury (332 thousands ha $-7.5 \%$ ), as properties capable of running the business efficiently, were put into administration. Moreover, the Agency signed agreements on payment of obligations of institutions and contractors. All the acquired obligations were paid by the end of 2000 according to those contracts;

- II period (1996 - 2003) - the process of leasing and selling agricultural properties is continued (average 150 thousands ha per year). At the same time in some areas, where before the noted demand was rather restrained, the derivative demand for lands appeared. As a consequence of those changes in demand, in 1999 legal regulations were introduced and they enabled organising limited auctions. Furthermore, following the market changes and in the perspective of upcoming joining the European Union by Poland, in 2003, based on the Act on Forming Agricultural System $(\mathrm{AFAS})^{3}$, notations were added to the Act on the Management of Agricultural Real Estate of the State Treasury from October 19, 1991. They introduced territorial limitations to the process of selling land by the Agency - up to 500 ha of farm lands per contractor could be sold. The area above that limit could only be leased. The Agricultural Property Agency was obliged to obeying rules from the AFAS in order to improve territorial structure of farm lands, prevent from excessive concentration of agricultural properties and to ensure that the farm households are run by qualified people. According to Article 23 of the Polish Constitution from April 2, 19974, family households are a base of state's agricultural system. Following the AFAS a family household is a household where the total area of farm lands (owned and leased) does not exceed 300 ha, which are run personally by a private farmer with proper qualifications and has at least 5 years of experience in working on a farm, who lives in the same commune as one of the agricultural properties included in the household;

- III period (2004 - September 16, 2011), increased demand for land and parallel shortening supply of lands from the Resource of CAP were noted. Around 100 thousands ha of lands were sold every year. As a consequence, prices of land rose 5 times from 3.7 thousand PLN to 17.2 thousand PLN - Figure 2). This was caused by joining the European Union by Poland and supplying Polish farmers with support (subsidies) from the Common Agricultural Policy of the European Union;

- IV period (September 16, 2011 - end of III quarter of 2015) - changes introduced in the the Act on the Management of Agricultural Real Estate of the State Treasury resulted in some major changes in the process of the Resource's management in the matter of tasks delivered by the APA. Those changes forced actions leading to firm management of possessed properties. Lease was acclaimed to be a temporary form of management and sale a firm one. In this period $120-150$ thousands ha of lands belonging to the Resource were sold per year. Moreover, in order to execute rules from the AFAS and in relevance to the upgraded AMAREST to the signed lease contracts, additional notations were added - within 6 months the Agency offered the tenants excluding $30 \%$ of the area of farm lands. Within 3 months from receiving notification, the tenant was obliged to decide and deliver a statement on accepting or declining the proposed changes. In case there was no such statement or the statement declined the proposed change, the tenant lost his pre-emption. Such changes were not introduced into agreements signed before the introduction of the Act on Changing the Act on the Management of Agricultural Real Estate of the State Treasury from September 16, 2011 if the total area of the leased farm land was not bigger than 300 ha. In that moment some doubts regarding its accordance to the Civil Code and to the Polish Constitution were raised, as it limited and deprived tenants from their acquired rights. The assigned authorisations will be of great importance for further activity of the APA, as they enable control (in the name of the State) over the agricultural properties market, as well as intervention during the trade by using national pre-emption (the Civil Code, article 599). In practice, it means that the Agency will be able to make decisions on form and way of managing the lands purchased this way.

3 The Act on Forming Agricultural System from April 11, 2003 (Dz. U. 2003, no 64, pos. 592)

4 Dz. U. from 1997 No 78, pos. 483, from 2001 No 28, pos. 319, from 2006 No 200, pos. 1471, from 2009, No 114, pos. 946. 


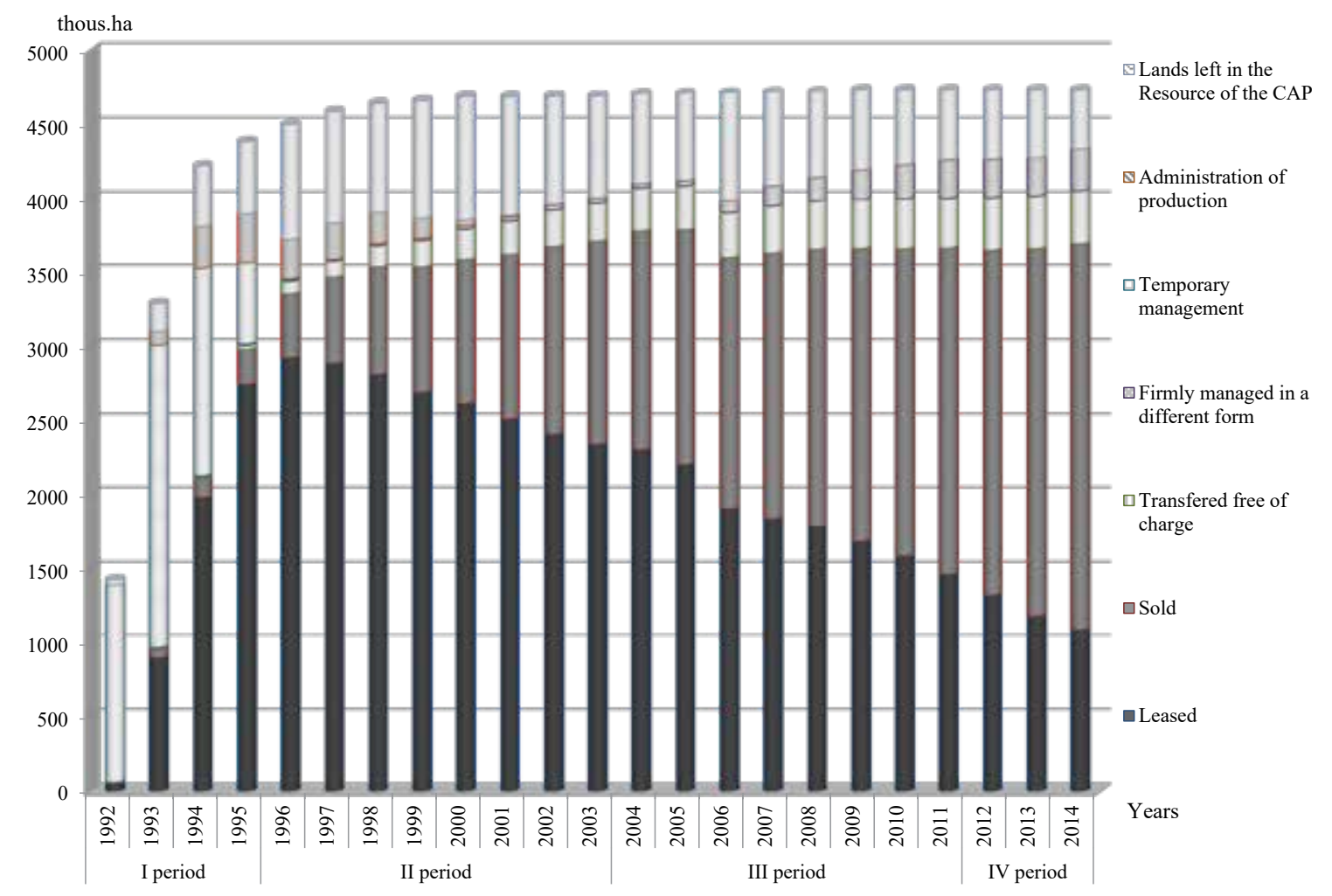

Source: own report on the basis of the data from The reports on activity for years $1992-2014$.

Figure 1. Management of lands from the Resource of CAP of the State's Treasury in years $1992-2014$.

Two forms had most important meaning in the process of proprietorial changes: lease (MarksBielska, 2014a) and sales. Proprietorial rights are separated from the rights to benefit of using it in case of agricultural lands in lease. Lease enables creation of new farm households or enlarging those already existing without engaging huge amounts of money as it would be required if the lands were to be purchased. The signed contract, according to the Civil Code ${ }^{5}$, obliges the landlord to transmit the land to the tenant and thus allow them gaining profit during the specified or unspecified period of time. The tenant is obliged to pay rent for the landlord in a form of money, different type of provision or by sharing a part of profit. The contract specifies rights and obligations of both sides. At the same time the tenant is obliged to use their rights obeying the rules of proper management and should not introduce changes in the contracted land without a permission of the landlord. The level of connection between the sides of the contract determines durability of the lease. Within the analysed period, the development of the institution of lease was influenced by the various socio-economic changes in the country. They were reflected both in lease rents and in land prices. The average lease rent grew by 5 times in natural measures (from $2.4 \mathrm{dt}$ in 1992 to 11.7 dt of wheat per 1 ha of land in 2014) and even 15 times in monetary measures (respectively from $56 \mathrm{PLN} \mathrm{ha}^{-1}$ in 1992 to $822 \mathrm{PLN}^{1 \mathrm{ha}^{-1}}$ in 2014) within the analysed period. Those changes were parallel to changes in national agricultural policy, which were reflected in changes in legal-formal regulations. They strongly influenced the stability and durability of management in this form. Another factor coming up to treating the lease as a temporary form of management was huge dynamics of changes in agricultural lands' prices. Rapid increase of prices resulted in huge interest in lands (demand), as it started being perceived as a form of investment - it gave the opportunity to augment the invested capital and, after joining the European Union by Poland, it provided the tenant with flowing benefits in form of direct subsidies for using the agricultural lands on the basis of CAP. Another important fact resulting from joining the Union was the agreed transformation period of 12 years which restrained foreigners from buying lands. The period was over on May 1, 2016. The ongoing changes were reflected in systematic growth of prices of farm lands. They grew 51 times higher within 23 years from 0.5 thousand PLN in 1992 to 25.6 thousand PLN in 2014. The biggest growth was noted after Poland joining the Union. The trend might be hold for such reasons as

5 Section II Lease from art. 693 to art.709 of the Act from April 23, 1964 - Civil Code Dz.U.2014.0.121 t.j. 


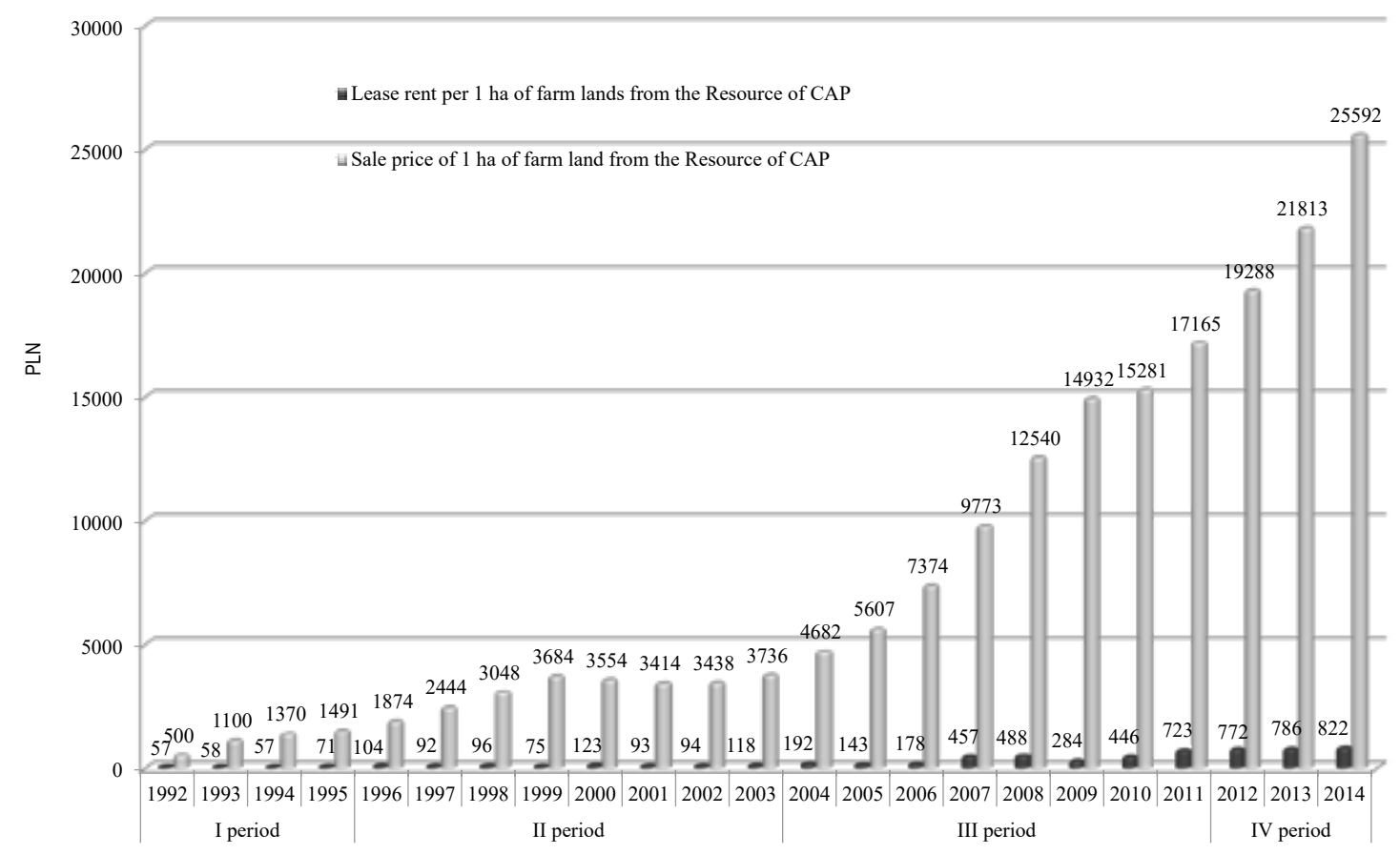

Source: own report on the basis of the data from The report... (2015).

Figure 2. Level of lease rent and sales prices of land from the Resource of CAP in years $1992-2014$.

smaller supply of lands and relatively high demand for them as well as limitations in trade of agricultural lands after the end of transformation period (Figure 2).

The Agency, in the process of managing the farm lands belonging to the Resource of CAP, creates a plan of land sales and monitors its execution every year. By the end of 2014 a total of over 2.5 MLN ha (more than $53 \%$ of the Resource of CAP) of lands were sold in 283 thousands of contracts (an average of 8.6 ha per contract). The analysis of level of land sales according to its territory shows some sort of asymmetry. In the group of over 100 ha contracts were signed with 3194 contractors (an average of 288 ha per contract) and they constituted for $36.6 \%$ of total (919 thousands ha). In the group of below 100 ha, 3194 contractors signed contracts for an average of 5.5 ha per contract. Assuming that lands of over 5 ha enlarged the already existing households or were the basis of forming new households, then it referred to merely $5 \%$ of country's households. It is characteristic that those contracts of 5 ha and more came up for $1 / 4$ of a total number of contracts (around 70.7 thousands), and they referred to $89.6 \%$ of sold lands. Such sales structure indicates that the process of proprietary changes helped to improve the territorial structure of agricultural households in Poland only a little. The scale of sold agricultural land to a relatively small group of contractors might cause some doubts and question the point of the changes from the perspective of social interest. At this point, it is crucial to underline that the process of land management caused various problems and a part of tenants and buyers, as a consequence of changes in economic situation (profitability of production) or wrong investment decisions made, went bankrupt. Therefore, part of land was returned to the Resource of CAP, and it required some costly actions connected with their afresh management. Table 1 presents exact numbers on sold lands grouped by the size of land per contract.

\section{Conclusions}

Results of the research indicate that the legalformal solutions, erecting from agricultural policy in the process of proprietary transformations in the state's agricultural sector, as well as used forms of management of agricultural properties of the States Treasury imposed the scope, paste and dynamics of changes in tasks and in structure of management of the Resource. In the process of reaching the main goal, which was to transfer proprietary rights on the Agency in the process of management of agricultural lands, various legal-formal solutions were created and they shape the current trade of agricultural properties. Several matters had an influence on 'popularity' of forms of management. Such matters are: changes in the socio-economic situation which were reflected in economic conditions connected with the profitability of agricultural production, availability of preferential credits, subsidies and dotation from European Union, legal regulations introducing limitations and other limits. As results of the research and experiences of the process of proprietary transformation in state's 
Table 1

Size and a structure of lands sold from the Resource of CAP according to the spatial groups - state at the end of 2014

\begin{tabular}{|c|c|c|c|c|c|c|c|c|c|c|c|c|c|}
\hline \multirow{3}{*}{$\begin{array}{l}\text { Size of land in a } \\
\text { contract }\end{array}$} & \multirow{2}{*}{\multicolumn{2}{|c|}{ Total sold land }} & \multicolumn{4}{|c|}{ Size of land } & \multirow{2}{*}{\multicolumn{2}{|c|}{$\begin{array}{c}\text { Total number of } \\
\text { contracts }\end{array}$}} & \multicolumn{4}{|c|}{ Number of contracts } & \multirow{3}{*}{$\begin{array}{c}\text { Averag } \\
\text { land } \\
\text { size per } \\
\text { contrac }\end{array}$} \\
\hline & & & \multicolumn{2}{|c|}{$\begin{array}{l}\text { Natural } \\
\text { person }\end{array}$} & \multicolumn{2}{|c|}{$\begin{array}{l}\text { Legal } \\
\text { entities and } \\
\text { others }\end{array}$} & & & \multicolumn{2}{|c|}{ Natural person } & \multicolumn{2}{|c|}{$\begin{array}{l}\text { Legal entities } \\
\text { and others }\end{array}$} & \\
\hline & $\begin{array}{c}\text { thous. } \\
\text { ha }\end{array}$ & $\%$ & $\begin{array}{c}\text { thous. } \\
\text { ha }\end{array}$ & $\%$ & $\begin{array}{l}\text { tys. } \\
\text { ha }\end{array}$ & $\%$ & $\begin{array}{c}\text { Number } \\
\text { of } \\
\text { contracts }\end{array}$ & $\%$ & $\begin{array}{c}\text { Number } \\
\text { of } \\
\text { contracts }\end{array}$ & $\%$ & $\begin{array}{c}\text { Number } \\
\text { of } \\
\text { contracts }\end{array}$ & $\%$ & \\
\hline to 0.99 & 55.7 & 2.2 & 54.8 & 98.5 & 0.8 & 1.5 & 130527 & 44.7 & 128660 & 98.6 & 1867 & 1.4 & 0.4 \\
\hline From 1.0 to 1.99 & 66.0 & 2.6 & 64.8 & 98.3 & 1.1 & 1.7 & 46405 & 15.9 & 45612 & 98.3 & 793 & 1.7 & 1.4 \\
\hline From 2.0 to 4.99 & 140.7 & 5.6 & 137.2 & 97.5 & 3.6 & 2.5 & 44331 & 15.2 & 43249 & 97.6 & 1082 & 2.4 & 3.2 \\
\hline From 5.0 to 9.99 & 174.1 & 6.9 & 168.0 & 96.5 & 6.0 & 3.5 & 24541 & 8.4 & 23692 & 96.5 & 849 & 3.5 & 7.1 \\
\hline $\begin{array}{l}\text { From } 10.0 \text { to } \\
19.99\end{array}$ & 276.1 & 11.0 & 262.4 & 95.0 & 13.8 & 5.0 & 19500 & 6.7 & 18561 & 95.2 & 939 & 4.8 & 14.2 \\
\hline $\begin{array}{l}\text { From } 20.0 \text { to } \\
49.99\end{array}$ & 671.0 & 26.7 & 603.7 & 90.0 & 67.3 & 10.0 & 20474 & 7.0 & 18599 & 90.8 & 1875 & 9.2 & 32.8 \\
\hline $\begin{array}{l}\text { From } 50.0 \text { to } \\
99.99\end{array}$ & 210.4 & 8.4 & 180.2 & 85.6 & 30.2 & 14.4 & 2973 & 1.0 & 2563 & 86.2 & 410 & 13.8 & 70.8 \\
\hline $\begin{array}{l}\text { From } 100.0 \text { to } \\
499.99\end{array}$ & 671.9 & 26.7 & 453.6 & 67.5 & 218.3 & 32.5 & 2864 & 1.0 & 2057 & 71.8 & 807 & 28.2 & 234.6 \\
\hline $\begin{array}{l}\text { From } 500.0 \text { to } \\
999.99\end{array}$ & 186.4 & 7.4 & 88.9 & 47.7 & 97.5 & 52.3 & 293 & 0.1 & 142 & 48.5 & 151 & 51.5 & 636.3 \\
\hline $\begin{array}{l}1000.00 \text { and } \\
\text { more }\end{array}$ & 60.6 & 2.4 & 16.6 & 27.4 & 44.0 & 72.6 & 37 & 0.01 & 12 & 32.4 & 25 & 67.6 & 1638.9 \\
\hline Land in total & 2513.0 & 100.0 & 2030.2 & 80.8 & 482.7 & 19.2 & 291945 & 100.0 & 283147 & 97.0 & 8798 & 3.0 & 8.6 \\
\hline \multicolumn{14}{|l|}{ including: } \\
\hline to 99.99 & 1594.0 & 63.4 & 1471.1 & 92.3 & 122.8 & 7.7 & 288751 & 98.9 & 280936 & 97.3 & 7815 & 2.7 & 5.5 \\
\hline 100.00 and more & 919.0 & 36.6 & 559.2 & 60.8 & 359.8 & 39.2 & 3194 & 1.1 & 2211 & 69.2 & 983 & 30.8 & 287.7 \\
\hline
\end{tabular}

*Does not include lands under buildings (also housing properties), separated objects, land of a specific character (with underground deposits, under waters, etc.) as well as non-agricultural lands

Source: own report on the basis of the data from The report... (2015).

agricultural sector show, legal solutions were not always giving equal protection of tenant's interest if compared to the interest of the State Treasury as it was the State Treasury who was prior. In 23 years of transformations more than $3.2 \mathrm{MLN}$ ha $(68.5 \%)$ of lands acquired by the Resource of CAP were firmly managed. 2.5 MLN ha (53\%) out of that were sold and all the obligations towards institutions and contractors were paid. By the end of 2014 only 1.5 MLN ha were kept by the Resource of CAP and 1.1 MLN ha out of it was leased, which combines for $23 \%$ of acquired lands although it allows fast temporary management of acquired agricultural properties of the State Treasury, and then, repurchasing them by the current tenants. Scope and structure of areas of farm lands under sales contracts indicates that it was purchased by a relatively small group of contractors. Such a structure of sold lands of the State Treasury might cause specific doubts and question the aim of such transformations from the perspective of social interest and of ethics.

\section{References}

1. Barańska, D., \& Michalak, M.J. (2008). Ethical Issues in Ownership Transformations in the Voivodship of Łódź (in:) 'Annales. Ethics in Economic Life' 2008, vol. 11, no 2, Lodz Archdiocesan Press pp. 121 - 129. 
2. Goodpaster, K.E., \& Matthews, J.B.Jr. (2007). Can a Corporation Have a Conscience? (in:) Social responsibility of enterprises. HBS Press, Helion Press, Gliwice, pp. $143-168$.

3. Jaworowski, J. (1999). Proprietorial changes in agriculture. UWM, Olsztyn. pp. 48 - 49.

4. The Civil Code - An act from April 23, 1964 - Journal of Laws of the Republic of Poland, 2014.0.121 t.j.

5. The Constitution of the Republic of Poland of April 2, 1997, Dz. U. from 1997 No 78, pos. 483, from 2001 No 28, pos. 319, from 2006 No 200, pos. 1471, from 2009 No 114, pos. 946.

6. Marks-Bielska, R. (2010). The market of agricultural land in Poland, Press of UWM in Olsztyn pp. $177-120$.

7. Marks-Bielska, R. (2013). Factors Shaping the Agricultural Land Market in Poland. Land Use Policy, 30, ELSEVIER; 791 - 799.

8. Marks-Bielska, R. (2014a). Conditions underlying the institution of farmland lease in Poland in 1992 2012. Agriculture \& Forestry, Podgorica. University of Montenegro. Vol. 60 Issue 4: 51 - 59. (Presented at the 5th International Scientific Agricultural Symposium AGROSYM 2014, Bosnia and Herzegovina, University of East Sarajevo, Jahorina, 23-26.10.2014).

9. Marks-Bielska, R. (2014b). Factors Affecting Farmland Management in Poland in $1992-2012$ in the Institutional Context. Economic Sciences for Rural Development 2014, Latvia University of Agriculture, Jelgava, No 35; 189 - 198 (International Scientific Conference Proceedings, 24 - 25 April 2014).

10. Mioduszewski, J. (2006). Management of agricultural properties of the State Treasury - chapter 1 (in:) Legal and economic aspects of management of agricultural properties of the State Treasury (red. Juchniewicz M.). UWM, WNE in Olsztyn, pp. $7-31$.

11. Mioduszewski, J., \& Niedzielski, E. (2012). The role of lease in management of agricultural properties of the States Treasury. PTE, Olsztyn, p. 128.

12. Nawrocki, T., \& Podgórski, B. (2009). The role of Agricultural Property Agency in enlargement and creation of agricultural households Agricultural Sciences Yearbooks PAN, WNE SGGW, Seria G - The Economics of Agriculture, vol. 96, from $3^{\text {rd }}$ Press release 'A Farm of Tomorrow', Warsaw pp. $67-76$.

13. Penc, J. (1997). Business lexicon. Press Agency 'Placet', Warsaw.

14. Statistical yearbook of Agriculture (1993). GUS, Warszawa.

15. Runowski, H. (2013). The circumscription of Polish agriculture after 1990 (in:) Proprietorial transformations in agriculture - 20 years of expertise and gaining perspective. (red. Runowski H.) pp. 7- 19. Press SGGW, Warsaw.

16. Wieteska-Rosiak, B. (2012). The Role of Corporate Social Responsibility in Building Competitive Region (in:) 'Annales. Ethics in Economic Life', vol. 15, Lodz Archdiocesan Press, pp. 339 - 346.

17. The Act from October 19, 1991 on the Management of Agricultural Real Estate of the State Treasury with further changes Dz.U. from 1991 No 107, pos. 464; Journal of Laws of the Republic of Polandfrom 1993 No 18, pos. 81 and No 60, pos. 280; Dz.U. from 1995 No 57, pos. 299 and No 101, pos. 504 and Dz.U. from 1996 No 59, pos. 268 and No 106, pos. 496.

18. The Act from September 16, 2011 on change of the Act on the Management of Agricultural Real Estate of the State Treasury and on change of some other acts (2011). Journal of Laws of the Republic of Polandfrom 2011 No 233, pos. 1382.

19. Ziętara, W. (2013). Reasons and conditions of proprietorial changes in agriculture. (in:) Proprietorial transformations in agriculture - 20 years of expertise and gaining perspective. (red. Runowski H.) pp. 39 - 50. Press SGGW, Warsaw. 